\title{
Personal Identity And Nostalgia For The Distant Land Of Past: Legacy Tourism
}

Nina M. Ray, Boise State University, USA

Gary McCain, Boise State University, USA

\begin{abstract}
"The past is certainly a distant land and getting there is a difficult and imperfect undertaking" (Brown, Hirschman \& Maclaran (2006). This paper explores motivations behind how consumers reach that "distant land." Over 1,000 respondents of a variety of ethnic groups show very different stories and diaspora timelines, but personal identity and connection with place are always top ranked motivations for interest in ancestors. How might groups, who may suffer from a lack of identity, fit into these findings when 'personal identity' is the number one reason why consumers engage in genealogy and legacy tourism? Whether a group is well defined (e.g., descended from Norwegian ancestors) or not well defined, results are remarkably similar.
\end{abstract}

Keywords: Legacy Tourism; Personal Identity; Nostalgia

\section{INTRODUCTION}

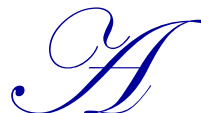

n advertisement for ancestry.com running during 2011 in the United States shows a woman exploring her family history stating that she felt a bit like the family detective in her search. Then she discovers that one of her ancestors really was a detective, so she is the "other family detective." The "detective work" and "thrill of the investigation" are some of the many motivations that people have when researching their family history, but "the problem with being a detective in one's own detective story is that the trail goes cold" (Brown, Hirschman \& Maclaren, 2000, pg. 167). "It is always the responsibility of someone else, usually a member of the family ... who has taken it upon themselves to tend the family tree ... The genealogical information they have is unfailingly incomplete. ... genealogy, in truth, is ultimately about absence, because there is always an empty space at the end of the search when whatever information there is finally runs out" (Brown, Hirschman \& Maclaren, 2000, pg. 162).

Brown, et al. (2006) observed, "The past is certainly a distant land and getting there is a difficult and imperfect undertaking" (Brown, Hirschman \& Maclaren, 2006, pg. 87). In their 2000 article, they termed the past as "a foreign country" (Brown, Hirschman \& Maclaren, 2000, pg. 174). In this paper, the authors emphasize those attempts of "getting there" (both figuratively and actually) to the "foreign country" from which ancestors left. "The present . . . can never quite escape the past" (Delaney, 2008, pg. i). All present-day legacy (or "ancestral," "diaspora," "roots," etc.) tourists need to get to that distant land; the route they take and the availability of the road maps (historical records) to help the modern day tourists get there, vary. For some, the journey is an important effort, necessary to one's personal identity; for others the destination (discovering records, finding an old homestead, etc.) is what adds to one's identity. Devine (2011) discussed the "key aspects of human experience" in his book on Scottish migration: ". . . identity, the relationship between host country and home country, nostalgia" (Devine, 2011, pg. xv).

In some cases, the ancestral homeland is well defined (e.g., Norway) and the present-day boundaries are similar to centuries-old boundaries. In other cases, descendants may wonder where the ancestral homeland lies. For example, America's Scotch-Irish (or Scots-Irish; the terms will be used mostly interchangeably in this paper) have no "homeland" called "Scotireland" to search for. The "plantation" of Scots in Ulster in the $17^{\text {th }}$ century from Scotland and the history of the migration of these Ulster-Scots to the new world is certainly complicated. Does this complication and confusion regarding an ancestral homeland affect the modern-day personal identity of descendants? Perhaps only in the discovery was there such a complication. 
If the only thing about the American Scots-Irish that one knows is the information from U.S. Senator Jim Webb's book, Born Fighting (2004), one has learned much. From the book and the associated Smithsonian Channel (in conjunction with Scottish TV, etc.) documentary series filmed in Scotland, Northern Ireland, and America, the reader is made aware that the Scots-Irish blended into the fabric of North America and are one of the few ethnic groups to not really identify themselves as an ethnic group. Well-known academic marketers (from both sides of the Atlantic) agree. The "Scotch-Irish exhibit several distinctive, ideological grounded behaviors that have characterized their subculture since colonial times. Paradoxically, many of these traits have become so naturalized over time that they have lost their ethnic label and are now viewed simply as American" (Brown, Hirschman \& Maclaren, 2006, pg. 86). Perhaps modern day descendants of the Scots-Irish are attempting to reclaim that personal identity (the top ranked motivation for interest in family history, as will be seen later in this paper).

Drawing on personal identity theory and self theory (e.g., Gould, 2010), this primary motivation of personal identity is explored in the context of searching for family history and the engagement in legacy tourism. The North American Scots-Irish will be the focus for much of the discussion of diaspora groups in this research because of their unique influence on the history of North America and also because of the supposed loss of their diaspora identity. Throughout the discussion, the role of nostalgia will be explored regarding its impact on and consequence of legacy tourism, especially for the tourism behavior of groups whose ancestors left the homeland several generations ago. These groups have very different stories and very different diaspora timelines from those descendants of more recent migrations (e.g., Sekhon and Szmigin, 2011).

\section{NOSTALGIA: YEARNING FOR THE PAST}

According to Sierra and McQuitty (2007), nostalgia is defined as "a yearning for the past, or a fondness for tangible or intangible possessions and activities linked with the past." As can be seen from this definition, not only tangible products, but activities, can "signal and reinforce consumers' self-identity" based on "shared heritage and memories with group members" (Sierra and McQuitty, 2007, pg. 99). However, Brown, et al. (2000) found "not a single interviewee would choose to live in times past, given the opportunity to do so." In the same discussion, they lament "the long forgotten P of place," (Brown, Hirschman \& Maclaren, 2000, pg. 181) and "Postmodern consumers, in short, are inclined to authenticate heritage time in terms of heritage space" (Brown, Hirschman \& Maclaren, 2000, pg. 178). Later in this paper, a "connection to place" is reported as a highly ranked motivation for interest in ancestors. Legacy tourism may be a way to satisfy one's yearning for that long forgotten place (i.e., the "distant land") in the past without having the ability or real desire to travel back in time. And while many legacy tourists claim that they wish to see the authentic locations involved with their story and to learn the authentic history of their ancestors, the consumers are really looking for "authentic inauthenticity" (Brown, Hirschman \& Maclaren, 2000, pg. 171) because consumers" attitudes toward the "good old bad days" is a "combination of pleasure and pain for both the past and the present" (Brown, Hirschman \& Maclaren, 2000, pg. 174). Although, Mkono (2011) recently found that "authenticity does matter" (Mkono, 2011, pg. 1). Some heritage consumers are "content to be connected to connectedness." One example is heritage parks; the marketing of them "is predicated on connectivity" (Brown, Hirschman \& Maclaren, 2000, pg. 175). "Marketing, then, is an integral part of the heritage package" (Brown, Hirschman \& Maclaren, 2000, pg. 178).

While Sierra and McQuitty did not discuss tourism (other than sports tourism) as one of their nostalgic activities, the authors of this present paper argue that legacy tourism certainly can "facilitate self-continuity by connecting with a desirable past" and for "knowing who we are" (Sierra and McQuitty, 2007, pg. 99). Specifically, "nostalgia is used to develop, sustain, and recreate individuals' identities" (Sierra and McQuitty, 2007, pg. 100). Membership in a cultural group (e.g., the Scots, the Irish, the Norwegians, etc.) is related to self-identity. According to Davies (2010, pg. 264), "the dream of sustainability . . is a nostalgia for the future." "Its fundamental desire is precisely that which the nostalgic yearns for - a stable home, free from the losses of time." Nostalgia is "erasure of the gap" between "nature and culture." "The nostalgic suffers acutely from the desire for an authenticity of origin that is common in some degree to us all" (Davis, 2010, pg. 266). . "whereby the idea of the fatherland (emphasis added) imprints itself at the centre of the brain and overpowers the flow of animal spirits" (Davis, 2010, pg. 267).

Sierra and McQuitty (2007) emphasize that both emotional (the "yearning"), as well as cognitive nostalgic elements, help consumers understand their identity. They also state that nostalgia can be from lived memories (real 
nostalgia) or learned memories (simulated nostalgia). Obviously, if one is engaged in legacy tourism to find the homeland of or information about one's ancestors, one is relying on learned memories. They found that yearning for the past is positively related to intent to purchase nostalgic products and that consumers can be simultaneously affected by both emotional and cognitive factors. They address service environments where marketers can evoke nostalgia in their managerial implications, including sports tourism. Another set of researchers address the impact of nostalgia on tourism. Acharya, Paudel and Hatch (2009) found that those who grew up in a small town, but are living under pressure of city life in adulthood (their operationalization of nostalgia), visit wilderness areas more frequently than others. This nostalgia is for leisure activities of their past and a "yearning for contact with nature" (Acharya, Paudel and Hatch 2009, pg. 449), so at least some researchers are investigating the tie between nostalgia and tourism.

In a classic article on the meaning of tourism, Belk states that "both physical journeys through time and space and metaphoric journeys are of interest." Traditional tourism has the physical aspects of transporting the body to new places. He suggests that "tourism can be viewed as a self-transforming ritual process." Metaphoric journeys include voyages of self discovery (Belk, 1997, pg. 23). He cites Horne (1992, pg. 5-6), "We can 'find ourselves'. Whether physically, intellectually, morally, or spiritually, we can feel better after we have done some touring." Belk describes two contemporary touristic rituals that involve art and shopping. The research in this study is on another expansion of the concept of self-identity, rituals involving the search for a link with ancestors, crossing the boundaries of time, between now and then, and of lineage, between me and my progenitors. The physical journey to ancestral homes joins with the metaphoric journey to meet with personal ancestors as they seek out their records and homes.

Brown, et al. (2000) caution that some may consider using marketing to "sell heritage" to be "blasphemous." However, these skeptics should be reminded that, "the most nostalgically freighted exhibits in the parks are associated with commercial life," such as their own example of the pharmacy in the Ulster-American folk park (Brown, Hirschman \& Maclaren, 2000, pg. 176). Gould (2010, pg. 181) investigated how individuals "define the self and view its functions including those in consumer behavior," which could include traveling to search out their ancestors. The creation of tourism products is ultimately a joint creation of the tourist consumer and the destination provider in a process of co-design and co-delivery of the benefits sought by the consumer conforming to the concept of "bringing the consumer in" (Cutcher, 2010; Learmans, 1993). The legacy tourists exhibit a manifestation of Czarniawska's observations that "the Self is historical, and is both constituted by and constitutive of community." "The self is produced, reproduced and maintained in conversations, past and present." That community is the legacy tourist with the community of the ancestors of the individual tourist's self. The conversations are the research and touring behaviors of legacy tourists (Czarniawska, 2000, pg. 275). Legacy tourists are consumers who are looking for tourism experiences to "link them with to others, to a community, to a tribe" (Cova, 1997, pg. 311). They have found their lineage to be the "linking value" that sustains their community or ancestral tribe connection. Their lineage, in some cases their ancestral name, forms their brand that yields value through a "sense of trust, affect, and shared meaning" (Arvidsson, 2005, pg. 236). A result of legacy tourism is an expansion of family histories through generations that gives those histories "staging value" that creates that "something more that helps intensify life's purpose and meaning" (Cutcher, 2010, pg. 88).

Basu (2001) describes the role of the search for identity in "hunting down home." Summarizing past works, he concludes that a current anthropological discussion revolves around two topics which compete with each other - a modern view which links identity with "fixity" and a postmodern one which suggests that personal identity and home are found in movement. Within the context of these two approaches, individuals form identity by personal narratives telling stories of themselves. He emphasizes the need to address both "the mobile and the static in these narratives of identity" (Basu, 2001, pg. 336). To Basu, home can be "deterritorialized" (Basu, 2001, pg. 336) and a myth of homeland can be created. Using the Scottish homecoming as a focus, he shows how 'Scottishness' can be expressed through very observable activities, such as clan societies and their gatherings and highland games. In some cases, this evidence of heritage has been reintroduced into the mother country where activities may have died out from the new world. Being "deterritorialized" has relevance for the Scotch-Irish who are descendants of mainly lowland Scots (in contrast to the highland Scots who celebrate highland games, etc.) who spent a century in Ulster (more or less today's Northern Ireland) and then left for the new world. In contrast to the obvious activities showing "Scottishness" (e.g., highland games), there are few activities (other than engagement in 
certain kinds of music performance; i.e., blue grass, etc.) which connote Scotch-Irish identity. However, both the diaspora Scots and the Scotch-Irish share an added layer of complexity in their ancestral identity. They certainly were traumatically displaced from their original homelands, but in many cases they were willing agents of the British Empire and hence aided in displacing others from their homeland sometimes.

While the idea of a "home" is often a mythical cognition, what is equally important is that this "home" is based on a material place and can be visited forming a union of the "imaginary and the material" (Basu, 2001, pg. 338) resulting in "sites of memory, sources of identity, and shrines of self" (Basu, 2001, pg. 338). In discussing sites of memory (places and institutions important to the group), Basu emphasizes the need for each person to become his own historian and individualize or personalize the cultural identity, thus making the sites of memory into the sources of identity and a "myth of the self" (Basu, 2001, pg. 342). In modern society, individuals have the ability to "invent themselves anew" (Basu, 2001, pg. 342) in the "narrative of landscape, landscape and identity." Giddens (1991) states "the reflexive construction of self-identity depends as much on preparing for the future as on interpreting the past" (Giddens, 1991, pg. 85). As one of Basu's respondents stated, "I define who I am by defining where I speak from in the family tree. .." (Basu, 2001, pg. 344). In discussing "shrines of self", Basu mentions how the search for personal identity demonstrates the many similarities between pilgrimage and tourism and how the self is the object of a quest. (Many of the terms Basu identified, such as "quest," "pilgrimage," etc., are used in the empirical data gathering legacy tourism project described later in this paper.) As Basu concludes, his "Hunting Down Home" article "narratives of identity of home and homeland clearly interact in complex ways" (Basu, 2001, pg. 346).

\section{SEARCHING FOR PERSONAL IDENTITY THROUGH LEGACY TOURISM}

Dickerson (2006, pg. W15) reports that a "widespread interest in genealogy is sweeping America." For many, researching one's family history involves tourism. This paper briefly explores the role that family history interest has in heritage tourism and illuminates the challenges and potential rewards of attracting legacy tourists. Interest and research on heritage/culture tourism generates numerous equally interesting definitions (Balcar and Pearce, 1996). For this research, the definition is "visits by persons from outside the host community motivated wholly or in part by interest in the historical, artistic, scientific or lifestyle/heritage offerings of a community, region, group or institution" (Silberberg, 1995, pg. 361) with recognition of Yale's (2004, pg. 1-40) observation that "the fashionable concept of 'heritage tourism' really means nothing more than tourism centered on what we have inherited, which can mean anything from historic buildings to art words to beautiful scenery." Suggestions are industrial heritage (e.g., power sources such as wind and watermills, steam engines, etc.), transport heritage, countryside attractions, and event attractions.

Certainly, the emotions associated with one's family history are an important part of "what we have inherited". A sub-segment of heritage tourism is comprised of tourists who desire to move beyond the scope of general ancestry to find specific links to ancestors or ancestry roots. These legacy tourists travel to seek out information or feel connected to their genealogical or family roots. Defining sub-sets of heritage tourism creates marketing opportunities to reach these segments by understanding their motivations. Nicholls, Vogt, and Jun (2004) identify specific heritage tourism types including legacy tourism, tourism related to genealogical endeavors, as described by McCain and Ray (2003). Many legacy tourists define heritage as their own family history.

Genealogy is a "significant part of Northern Ireland's tourism industry" (Evans, 1998, pg. 14), which is part of approximately 200 million pounds (around 315 million U.S. dollars) in revenue per annum from foreign tourists (Collins and Beggs, 2000). In the North of Ireland, the Department of Culture, Arts and Leisure sponsors a "comprehensive examination of genealogy-related services" recognizing the "role of family history in promoting tourism" (Mackenzie, Slater, and Roberts, 2004). Sponsors of the "Who Do You Think You Are?" National History Show in London promoted this event "[a]s the largest event of its kind; the entire event will attract up to 20,000 visitors from across the UK. This innovative, national event is set to become the premium event for anyone with an interest in the history market - an unbeatable opportunity to meet new customers and develop your business." Exhibitors will "have the chance to meet . . articulate, and highly educated . . . consumers - each with money to spend on a subject that is important to them" (Exhibiting, 2008). Therefore, not only is there a large population of history seeking tourists, but these consumers have demographics favorable to marketers. 
Searching for ancestors may be beneficial to one's mental health. Psychologists have shown that thinking about our ancestor's increases self-esteem. Scholars at the universities of Graz, Berlin and Munich say the "ancestor effect" boosts performance on intelligence tests (Fischer, Sauer, Vogrincic and Weisweiler, 2011). Writing and thinking about ancestors led students to do better on verbal and spatial tests than those who thought about themselves or friends. Sometimes learning about one's ancestors may have a bittersweet effect on one's mental health. Craig (2005) asked, "What does it mean to be more-or-less affluent American but trace your origins to the bleak west coast of Co. Clare, an area once famous for the intensity of its privations?" The "same but different" catchphrase takes on meaning as "his visits to the West of Ireland began to seem less like episodes of time-travelling and more like a homecoming."

A recent article, "Diaspora Tourism and Homeland Attachment" (Huang, Haller and Ramshaw, 2012) states that some societal benefits of diaspora/legacy tourism may be "when they travel back 'home', they will be more interested in sustaining and improving the well-being of the local people, culture and environment." This motivation may be especially prevalent with young second-generation adults - those beginning a career. This demographic finding is in contrast to others (e.g., Ray and McCain, 2009a) who found that those who seek their roots are usually older. Certainly a clearer demographic definition of legacy tourists would be a valuable contribution from future researchers. Tourism to "home and familiar places" certainly relates to diaspora or legacy tourism. VHFP (visiting home and familiar places) is an expansion of VFR (visiting friends and relatives) tourism (Pearce, 2012). The author admits that important related research to VHFP is "travel to the locations important in their own life" (pg. 1027) but also "visiting the places inhabited by their forefathers. ... The value of this literature . . . lies in emphasizing the roles the past can play in shaping people's travel motivation and identity quests." "The individual's challenge is to celebrate the past while making connections with the present and the future" (pg. 1034). In going home to familiar places, tourists are presented with emotional and cognitive cues. "Sensory and environmental cues trigger mindfulness and confront tourists and visitors with identity issues and images of change" (pg. 1042).

\section{IDENTITY OF THOSE LEFT BEHIND}

"Genealogical insights, just like historical awareness, can strongly influence the shaping of personal and collective identities" through "diasporic consciousness, an awareness of the possibility of multiple identities and belonging, of experiences shared by people in different generations and locations, people with whom the individual student can become acquainted even if they are long since dead, and, in particular, an awareness of how different people can share what is important about a place, yet without any of them having to own it" Lunney (2011). Earlier (2009) she argued on behalf of those who did not emigrate and on what losing so many people to emigration did to society and the identity of those left behind. There are economic costs (of raising children only to lose them to another land) and self-esteem issues due to the "high-level academic historiography" (Lunney, 2009, pg. 89) of being told that brightest and the best left for the new world. By logic, that leaves the second-rate or third-rate behind to breed today's descendants. She specifically is critical of "the growth industry of books and other media widely available in Britain and Ireland, focusing on the achievements of Ulster or Irish born emigrants, particularly focusing on those who went to the US, for instance, to become 'Scotch-Irish' in Appalachia' (Lunney, 2009, pg. 90).

In Norway, the President of the Tysvær Historical Society (area of Norway where Norwegian emigration began) also laments, "some of the best of our people" had to leave Norway and now Norway has as many members of the diaspora as it has living in Norway. The Norwegian discussion is relevant here because Norway tells its visitors that after Ireland, it had the largest numbers of citizens emigrating to North America. Patrick Fitzgerald (2005), one of the experts portrayed in Senator Webb's Born Fighting series, wrote in "Come Back Paddy Reilly" about the underexplored phenomenon of return migration. "The exploration of previous internal migration, later onward migration, and return migration, can provide an enriching and revealing context through which to understand the whole emigrant experience" (Fitzgerald, 2005, pg. 48).

The tourism equivalent of this return migration is the "returning Yank syndrome". Hallissy (2006, pg. 174) states, "While the exile is a dramatic, even tragic figure, in Irish literature, the returning Yank is often a satiric or comic one. Either he has become successful and wants to show off or he has failed and returns in disgrace. Either 
way, he returns more a Yank than an Irishman and does not fit into Irish society anymore." Basu's (2004) research from Scotland reports that these tourists to the ancestral homeland are sometimes ridiculed and considered to be "emotional cripples" by the locals. One of the authors of this paper found that when she asked visitors to a booth at a Highland Games in the U.S. to participate in the legacy roots study mentioned later, a would-be participant's response was, "No, I know who I am! I have no need to trace my roots" (she is a native of Scotland). Even so, while there were some negative feelings surrounding Scotland's 2009 "Homecoming" to celebrate the $250^{\text {th }}$ anniversary of the birth of the national poet, Robert Burns (mostly over unpaid debts to creditors, e.g., Ferguson 2011), there was little reporting of visitors not being made to feel welcome as they "returned home."

One needs to note that many of those "left behind" benefited from emigration. On a recent trip to Norway, this was made clear when visiting a family farm. The authors saw the home where the great-grandfather of a respondent was born but now being shown to them by the living descendant (and second-cousin to the respondent) of this Norwegian-American. This modern day generous host might not have currently owned the portion of the old farm that he does if many of the children had not gone to America in 1868. The farm would have been divided up even more at that time. His father would not have been able to build the home on the farmland in which this present-day descendant was born.

\section{IN THEIR OWN WORDS}

\section{Tracing One's Ancestors}

According to one family historian researching Norwegian roots in the mid-twentieth century (1947), the reason for working on the family tree is "challenge of the unknown" (Rosedale, 1996, xiii). It is also a "natural tieinto history, geography, and travel." Even in 1947, family historians were interested in the IRL (in real life), as the Wall Street Journal discusses (Tergesen, 2011). "It's all about walking in your ancestors' footsteps," says Megan Smolenyak, author of "Who Do You Think You Are? The Essential guide to Tracing Your Family History" (Tergesen, 2001, pg. R5). In 2011, a descendant of that 1947 author who went to Norway in 2011 to see the land of his ancestors says, "I'd like to find out where my relatives lived, how they lived, and what the descendants who stayed in Norway are doing now." The authors personally know this traveler and can testify that he is not normally an overly sentimental person. However, one does have to wonder what role sentimentality and nostalgia play in such searches. Few tourism experiences may be more emotional and nostalgic than those involving tourists' own personal connection to their own heritage.

Writing about the Orkney Islands off the north Scottish coast, Basu (2007, pg. 210) notes that ancestral tourists are not only interested in visiting a location relevant to their particular ancestry and where they have some documented connection, but are also drawn to archaeological areas, especially prehistoric ones in areas nearby. One respondent reflected, "These are the sights they would have seen and this is the environment that they would have been living in on a day-to-day basis" (Basu, 2004, pg. 37). In the case of Orkney, archaeology tourism - a part of heritage tourism - is becoming an important source of tourist revenues. Increasingly, tourists visit archeological sites such as the Neolithic village of Skara Brae, the chambered cairn of Maeshowe, and the Ring of Brodgar stone circle (Downes, 2008). Basu proposes these ancient sites take on even more meaning for ancestral tourists because they believe the monuments were sacred sites to their own ancestors. The journey to these sites is therapeutic, according to Basu (2007, pg. 164). He quotes a tourist from Colorado, "it is precisely by revisiting the landscape that we begin to participate 'in the quest' for our healing and reconnection." Part of that quest is finding oneself. One of Basu's respondents (2007, pg. 224) wrote:

... this is finding out who I am ... I feel a sense of belonging to this area, but you can never know it because it's an emotion, not a tangible thing ... it's in here [pointing to heart] and it's in here [pointing to head].

\section{The Joy Of Helping Others}

Certainly getting tourists to their ancestral homeland is big business and many nations actively market their ancestral trails. Both Ireland and Scotland are mentioned in a recent Wall Street Journal article as relying heavily on legacy tourists. In North America, localities such as Nova Scotia "have recently begun promoting genealogical 
records on government-sponsored tourism websites" (Tergesen, 2011, pg. R5). Two locations in the United States Salt Lake City, Utah, and Fort Wayne, Indiana - have major family history libraries with extensive records. One example is Salt Lake City, Utah's Family History Library. Many of the Library's daily 1,900 visitors (only a minority are Mormons) come from other countries (Eastman, 2011) and genealogy is prominently displayed on the City's Convention and Visitors Bureau website www.visitsaltlake.com/what_to_do). Even the second largest genealogical collection in the United States (Fort Wayne, Indiana) promotes its Number 2 ranking as still a place "to go to find out where you're from" (The Genealogy Center, 2008). The Salt Lake City Family History Library is one of the top tourist attractions in the state of Utah, showing that one does not have to be in "the mother country" to benefit from legacy tourism. In "Genealogical Tourism," Carla Santos and Grace Yan (2009) emphasise the "lived experience" of travel to genealogical libraries. Since viewing documentation in libraries can provide a "powerful stimulus" for later tourism to ancestral locations, both tourism to libraries and the mother country are important research endeavours for tourism marketers (Santos and Yan, 2009, pg. 2).

In some cases, municipalities in the "old world" can benefit by not only having tourists come "home" but by creating exhibits about the home and the migration voyage and having those exhibits showing the migration. As just one example seen in this research, the "Promise of America" exhibit housed in Tysvær, Norway, has, in fact, toured America. Even those who "got it all started" are honored in some cases. In Tysvær, there are several monuments to Cleng Peerson, the "father of Norwegian emigration" ("A Genuine Emigrant," 1998).

Apart from the economic aspect, there is also an emotional benefit to helping others find their ancestors. When a Sons of Norway Lodge in Norway was contacted to help find some local relatives of the above-mentioned Norwegian-American tourist, the Lodge Secretary responded, "I am so excited for you" when the Lodge did, in fact, find local modern-day relatives. This person was disappointed that she would be out of town when the American Norwegian would be arriving. She said that she was pleased that the group had "been successful in finding relatives. This must be very exciting for you. I would love to meet you while you're here, but I'll be on vacation that week, seeking my own roots north in the Sognefjord where my father comes from. I like to visit my family up there, this time bringing one of my daughters with me. It is very important that the future generation knows where we come from." Certainly this statement reflects the fact that those in the "new world" are not the only ones who are interested in tracing their family history and her reason (need to inform the future generation) is a common motivation, coming from the old world or new. One researcher at the Norwegian Migration Center in Stavanger, Norway, said that "it is very pleasant" to help family historians find their roots and that he knew that it would be "very exciting for you to visit the family farm."

The head of the Historical Society in Tysvær, Norway, tells of a famous banner from the region which was paraded in many U.S.-Norwegian celebrations until it disappeared forty-some years ago. By chance, when visiting the U.S. to gather research for a book on a famous Norwegian-American author, one of the present-day Americans being interviewed mentioned that he had some old cloth banner in his basement. It turned out to be the item lost for 40 years. It was sent back to the Tysvær region (a form of almost reverse-migration) and the President of the Historical Society is "very proud to receive back" the banner.

\section{METHODOLOGY AND RESULTS}

\section{Why Do Later Descendants Care?}

As part of a "legacy tourism" project, from 2005 to 2009, data were gathered from over 1,000 respondents at family history, genealogy, and general history events in North America, the United Kingdom, and Ireland. A variety of ethnic groups are represented, such as those with Basque, Latvian, Norwegian, Irish, Scottish, and ScotchIrish backgrounds, etc. The authors were in Norway during the 22 July, 2011 bombings and shootings and noticed that, naturally, at the time there was much self-reflection in the nation about what it means to be Norwegian and a discussion about values that Norwegians hold dear. These tragic events do serve to remind that the discussion of heritage and one's ancestry can take on a very timely and poignant meaning. A pen-and-paper survey instrument concerning motivations for interest in family history was derived from terms in Basu's account of an ancestral tourism group to Orkney (2004) and feedback from early interviews. Each potential respondent was asked in person to complete a one-page (two-sided) survey either at the gathering or at one's convenience to be mailed back later. 
Appearing in person at the data gathering events allows the researcher to engage in conversations with respondents. For good or bad, the sampling was of a "snowball," non-probability nature. What began as a matter of geographic and personal ethnicity convenience sample for the researcher turned into a string of contacts, with a number of referrals to relevant future participants and group data collection opportunities.

Table 1 shows the set of motivations and ranks. Note that the role of identity is evident; both "personal identity" and "recovery of social identity" are listed as being main motivations by at least $9.7 \%$ of all respondents. Norwegian-Americans, interviewed through U.S. Sons of Norway lodges $(n=104)$, have the same top three motivations in the same order as the general populations of respondents. The Scotch-Irish, surveyed at various events concerning their Ulster-American heritage ( $\mathrm{n}=206)$, have the same top two motivations in the same order but list "obligation to ancestors" as the third most important reason for tracing their family history. Additionally, respondents were asked if they had ever traveled specifically to find information on their ancestors and the number of such trips they have taken. These respondents had the opportunity, through open-ended questions, to further express their reasons and motivations. In addition to the researcher-provided list of motivations in Table 1, respondents were also asked to state their own reasons for interest in family history. Across the board, many of the reasons ("in their own words") for why descendants care about family history are: "To experience the places, artifacts, and activities that authentically represent the stories and people of the past and present" (includes cultural, historic, and natural resources), "to engage in genealogical endeavors," "to search for information on ancestors or ancestral roots," "to feel connected to ancestors or ancestral roots," "to experience ancestors' home," "to find birthplace of ancestor," "to gather family medical history," "to feel the joy of the search," "to have the thrill of the adventure."

Table 1: Reasons for Interest in Family History (1,024 of total N=1,057 Responding)

\begin{tabular}{lc}
\hline Motivations Indicated By Entire Data Set & Percent of Respondents Indicating \\
Personal Identity & $43 \%$ \\
Connection with Place & $42.9 \%$ \\
Intellectual Challenge & $33.1 \%$ \\
Obligation to Ancestors & $30.8 \%$ \\
Discovering Continuities & $27.5 \%$ \\
Completing the Circle & $19.3 \%$ \\
Quest & $14.6 \%$ \\
Finding Oneself & $13.7 \%$ \\
Closing the Gap & $9.9 \%$ \\
Recovery of Social Identity & $9.7 \%$ \\
Remainder (pilgrimage, homecoming, true home, sacred, community, magical feeling, & $8 \%$ or less \\
inward journey) & \\
\hline
\end{tabular}

Specifically, when Norwegian Americans were asked, 42 of them elaborated with their reasons. Some of these reasons are "connecting/reuniting with relatives," "see if I can find any relatives in Norway," "curiosity (about medical history)," "why immigration to America; why all the name changes?" "discovering sense of place," "going to Norway for grandparents - they longed to return," "pride in ancestors," "honoring ancestors," and "passing down information to children." With these comments, one can see the importance about learning the immigrants' stories, passing those stories on to the next generations, and finding living relatives. Of 667 of the total data set (those who actually have taken a "legacy" trip), 74\% (the highest percent) said that finding a specific location relevant to one's own ancestor was what they hoped to achieve out of genealogy travel. Close behind (70\%) is seeking information (e.g., in libraries, etc.) was what they hoped to achieve. Distant third, but still with $42 \%$, is "finding living relatives."

The importance of finding a specific location does differ among ethnicities (Chi-square 15.12, $\mathrm{p}=.019$ ). The highest are those of Scottish descent - 78\% (higher than statistically expected). Next are the Irish with $75 \%$ (higher than statistically expected). There is a U.S. group based on general interest in family history, not based on national ancestry. Seventy-four percent of them say "finding a specific location is important" is about what is statistically expected. Other groups show less than statistically expected - Norwegians (65\%), Basques (57\%), and Latvians (55\%). The lower-than-expected percentages of Norwegians and Basques is interesting given that a 
Norwegian and Basque surname is taken from the exact name of geographic location or family farm. Some participate in research resulting in legacy tourism to help others find their roots. Forty-seven percent said seeking information was an important reason when seeking ancestors of a spouse or friend. Forty-two percent said finding a specific location relevant to ancestor of spouse or friend is important. Twenty-one percent said they engaged in research in order to find living relatives of a spouse or friend.

Another aspect of the methodology was to visit specific areas in Europe known to be centers of major emigration to America. For example, the Tysvær region of Norway is known as the location of original Norwegian emigration, so visiting with nearby Migration Centers and local historians resulted in long interviews with "those left behind" and those who help tourists find their roots. While not necessarily the main center of Irish emigration, the Ulster-American Folk Park and Centre for Migration Studies in Omagh, Northern Ireland, has been visited many times by the authors and information from interviews with the top management of the Centre have been incorporated into this paper.

\section{The Scotch-Irish: What Do We Call Ourselves? What Is The Mother Country?}

Norwegian-Americans and the Scotch-Irish are two groups focused on for this article. The two groups are very different. Norwegians emigrated to America mostly in the $19^{\text {th }}$ century, while the Scotch-Irish ancestors came in the $18^{\text {th }}$ century. Norwegians can clearly trace their ancestry back to a very specific modern-day sovereign nation, whereas the Scotch-Irish do not have that luxury. Records for Norwegians are often very good, but Scotch-Irish ancestors from Ulster often have had their documentation destroyed. Norwegian blood in the diaspora may be diluted, but those who call themselves "Norwegian" know what that means. Oftentimes the descendants of diluted Scotch-Irish blood do not have a clear idea what being Scotch-Irish means. The number one rank of personal identity is interesting given Senator Webb's discussion of how the Scots Irish blended into the fabric of North America and are one of the few ethnic groups to not really identify themselves as an ethnic group. Well-known academic marketers (from both sides of the Atlantic) agree. The "Scotch-Irish exhibit several distinctive, ideological grounded behaviors that have characterized their subculture since Colonial times. Paradoxically, many of these traits have become so naturalized over time that they have lost their ethnic label and are now viewed simply as American" (Brown, et al., 2006, 86). Perhaps modern day descendants of the Scots-Irish are attempting to reclaim that personal identity (the top ranked motivation for interest in family history). Of course, "some care and some do not. Some think it matters and some do not" (Webb, 2004, pg. 342); and as Roe, Schaafsma, and Gutierrez (2009) point out, Scotch-Irish acculturation did not "preclude ethnic continuity" (pg. 2).

When a student of one of the authors in the U.S. Pacific Northwest identified herself as "Scotch-Irish," she was asked what this identity meant to her. Her response was:

My paternal grandmother and grandfather told me about my Scotch Irish heritage. Apparently, I am of this lineage on both sides, although on my grandfather's side there is more Scottish than Irish. To me, this term means that my ancestry is that of two countries that at some point intermixed and created a new third heritage. In my general life, this heritage has not been a big deal. During my childhood, it was important as my grandfather had a small leatherworking booth at a Highland games held near Seattle. After becoming estranged from him after my father died, the value I had placed on this heritage became diminished until I saw advertisements for local Highland games and it brought back pangs of nostalgia.

So, her grandparents tried to pass along a "Scotch-Irish" heritage to this woman, but it is the Highland Games which cause pangs of nostalgia - a very Highland Scot, not Scotch-Irish, event.

Certainly, with recent political emphasis in the U.S. to return to the values of the nation's founding fathers, determining the values of those fathers and their descendants is important. An interesting modern day practical marking ramification of this return to values exemplified by the recent political "tea party" movement is that "colonial garb is back in style" (Levitz, 2010, Oct. 14), that "Founding-Father Nostalgia and Tea Party Have Many Americans Playing Dress Up," and how last year's Halloween Doesn't Fully Explain the Spike in Powdered-Wig Sales." Some scholars (e.g. Walker, 2009) expand on this supposed loss of Scotch-Irish identity, citing U.S. census figures where many specifically indicated Scotch-Irish ancestry. According to Walker (2009), around three to four 
million have indicated specific Scotch-Irish identity on recent U.S. censuses. Twenty percent of those indicating Scotch-Irish on the 1990 census are located in the "West'. Montana was one of four states that had the highest proportion of its population with this background. "Mobility became the hallmark of the Scotch-Irish" (MacMaster, 2011). This mobility enabled them to don "other hats" and also (and perhaps more importantly) become southerners, westerners, etc.

\section{LIMITATIONS}

While the authors believe that the example groups described here (e.g., the Norwegians, Scotch-Irish) do accurately portray many characteristics of personal identity and resulting legacy tourism, these groups are partially chosen because the authors have personal contacts with Norwegian and Scotch-Irish (as well as Scottish and Irish) groups. The historic migration patterns of these groups to the new world did not take place recently. While mentioned briefly in this paper, but not explored at length, newer migrant groups such as Latvians (if migration in the middle of the twentieth century can be considered "new") who have very identifiable social and cultural groups in North America could be included in future research. Perhaps one caveat from a popular novel (Tipperary), which pertains directly to Ireland but perhaps can be applied to many locations pertinent to this research, says it best (Delaney, 2008, pg. xi):

A modern commentator tries to remain objective, until he discovers deep in his researches, that in Ireland everything is personal, especially the past.

\section{CONCLUSIONS}

Early in this paper, the authors ask, "Does this complication and confusion regarding an ancestral homeland affect the modern-day personal identity of descendants?" Surprisingly, whether one's identity is well defined (e.g., from Norway) or one's ancestral identity is more diluted and less defined (e.g., the Scotch-Irish), the reasons for searching for ancestral roots are very similar. "Personal identity" and "connection with place" may well be the top motivators, but even some of the secondary motivations of discovering continuities, finding oneself, and recovery of social identity speak to the identity motivations of these tourists. Even "intellectual challenge," while a less salient motive, is reflected in the energy and initiative this segment exhibited as they engage in genealogical endeavors and search for information on ancestors or ancestral roots which leads up to their tourism. According to one family historian researching Norwegian roots in 1949, the reason for working on the family tree is "challenge of the unknown" (Rosedale, 1996, pg. xiii). Legacy/diaspora tourists are often older and have more time for leisure travel, although some researchers are beginning to investigate young adults engaging in diaspora tourism (mostly secondgeneration).

While having access to previous family history research is enviable, modern day researchers are able to use modern day technology. John Young, Professor of History at the University of Strathclyde (also prominently featured in Senator Webb's Born Fighting documentary), while speaking about his own Australian relatives who have thoroughly researched his family history, states, "With technological developments, genealogy has become more sophisticated and it is now possible for people of Scottish descent to come back here with a quite sophisticated and detailed knowledge of their ancestors and where they came from" (Young, 2011). Many countries are not taking full advantage of the roots tourism market. For example, contacts in Norway told the researchers that Norway had been planning a type of "ancestral trail" (such as promoted in Scotland) but it has not launched yet. There is a fear of competition in the legacy tourism market. One friend in the UK, when speaking about Scotland's homecoming in 2009, remembered that an Ulster Scots activist who writes a column in a newspaper, suggested that the Scottish Homecoming event was part of a ploy to take U.S. tourists away from Ulster for their dollars.

The significant interest in ancestral homelands is more than just seeking historic monuments of their nationality. It is often more personal. Legacy tourists need to experience the places, artifacts, and activities that authentically represent the stories and people of the past and present. In previous research, Ray and McCain (2009b) found that of those surveyed, 65\% (most stated) cited finding a specific location as important; therefore, researching the methods for how to best sustain that location for future generations are important. Future researchers will continue to research the importance of actually getting to a physical place but will also expand their 
studies to include associated aspects of the legacy tourism bundle. One example is the understanding the role that language understanding and learning can play in the experience. Some nations may begin to follow Scotland's lead to explain and promote "learning the language of your ancestors" (ancestralscotland.com, 2011). Whatever the diasporic origin of the respondents studied, there appears to be a personal identity motivation that prompts feelings of nostalgia to experience a home not seen but inherited from our ancestors.

\section{AUTHOR INFORMATION}

Nina M. Ray is a Professor of Marketing and International Business at the College of Business and Economics, Boise State University, Boise, Idaho, USA. In addition to legacy tourism her research interests include heritage tourism, historical re-enactments, and language/linguistics applied to marketing. Publications appear in Global Business Languages, Leisure Studies, Tourism Management, Journal of Scotch-Irish Studies, and the International Journal of Culture, Tourism, and Hospitality Research among others. Department of Marketing and Finance, Boise State University - MS1630, Boise, ID 83725; E-mail: nray@boisestate.edu

Gary McCain is a Professor of Marketing at the College of Business and Economics, Boise State University, Boise, Idaho, USA. His research interests are in the areas of legacy and heritage tourism, services marketing, and new product development. Publications appear in Leisure Studies, Journal of Pediatric Orthopaedics, Rapid Prototyping, Tourism Management and the International Journal of Culture, Tourism, and Hospitality Research, among others. Department of Marketing and Finance, Boise State University - MS1630, Boise, ID 83725; E-mail: gmccain@boisestate.edu (Corresponding author)

\section{REFERENCES}

1. Acharya, R.N., Paudel, K.P., \& Hatch, L.U. (2009). Impact of nostalgia and past experience on recreational demand for wilderness. Applied Economics Letters, 16(5), 449-453.

2. A Genuine Emigrant. (1998). The America pioneer Cleng Peerson. Brochure, Kulturetaten Tysvær, Norway.

3. Ancestralscotland.com. (2011). Learning the Language of your Ancestors. Retrieved December 1, 2011, from Visit Scotland Official Ancestral Tourism Web site: http://www.ancestralscotland.com/research-yourroots/language-of-your-ancestors/

4. $\quad$ Arvidsson, A. (2005). Brands: A critical perspective. Journal of Consumer Culture 5(2), 235-58.

5. Balcar, M. J. O., \& Pearce, D.G. (1996). Heritage tourism on the west coast of New Zealand. Tourism Management, 1(3), 203-212.

6. Belk, R.W. (1997). Been there, done that, bought the souvenirs: Of journeys and boundary crossing. In S. Brown \& D. Turley (Eds.), Consumer research: Postcards from the edge (pp. 22-45). New York: Routledge.

7. Basu, P. (2001). Hunting down home: Reflections on homeland and the search for identity in the Scottish diaspora. In B. Bender \& M. Winer (Eds.), Contested landscapes: Movement, exile and place (pp. 333348). Berg: Oxford.

8. Basu, P. (2004). My own island home: The Orkney homecoming. Journal of Material Culture, 9(1), 27-42.

9. Basu, P. (2007). Highland homecomings: Genealogy and heritage tourism in the Scottish diaspora. New York: Routledge.

10. Brown, S., Hirschman, E., \& Maclaran, P. (2000). Presenting the past: On marketing's re-production orientation. In S. Brown \& A. Patterson (Eds.), Imagining marketing: Art, aesthetics and the avant-garde (pp. 141-184). New York: Routledge.

11. Brown, S., Hirschman, E., \& Maclaran, P. (2006). Two continents one culture: The Scotch-Irish in southern Appalachia. Johnson City, Tennessee: The Overmountain Press.

12. Collins, N., and Beggs, R. (2000). Government and tourism in Northern Ireland. In N. Buttimer, C. Rynne \& H. Guerin (Eds.), The heritage of Ireland. Cork, Ireland: The Collins Press, 499-505.

13. Cova, B. (1997). Community and consumption: Towards a definition of the "linking value" products or services. European Journal of Marketing, 31(3/4), 297-316. 
14. Craig, P. (2005, August 19). Booking Passage: We Irish \& Americans by Thomas Lynch-The poet undertakes a reviving journey home. The Independent. Retrieved December 5, 2011, from The Independent Web site: http://www.independent.co.uk/arts-entertainment/books/reviews/booking-passage-we-irish-ampamericans-by-thomas-lynch-503384.html

15. Cutcher, L. (2010). Local heroes: Co-producing history, 'community' and the self. Consumption Markets and Culture, 13(1), 79-90.

16. Czarniawska, B. (2000). Identity lost or identity found? Celebration and lamentation over the postmodern view of identity in social science and fiction. In M. Schultz, M.J. Hatch \& M.H. Larsen (Eds.), The expressive organization: Linking, identity, reputation and the corporate brand (pp. 271-283). Oxford: Oxford University Press.

17. Davies, J. (2010). Sustainable nostalgia. Memory Studies, 3(3), 262-268.

18. Delaney, F. (2008). Tipperary. New York: Random House.

19. Devine, T., (2011). To the ends of the Earth: Scotland's global diaspora 1750-2010. Washington, DC: Smithsonian Books.

20. Dickerson, D.J. (2006, 17 November). Searching for roots. The Wall Street Journal, W15.

21. Downes, J. (2008). Description and Status of the Heart of Neolithic Orkney World Heritage Site: Part 1, Agenda Setting. Retrieved December 5, 2011, from Historic Scotland Web site: http://www.historicscotland.gov.uk/orkney-agenda-part1.pdf

22. $\quad$ Eastman, Dick. (2011, February 6). The Family History Library - In Salt Lake City and Near You. Eastman's Online Genealogy Newsletter. Retrieved December 5, 2011, from Geneological Society of South Whidbey Island Web site: http://www.gsswi.org/FHLFHC.php

23. Exhibiting. (2008). Who Do You Think You Are? Retrieved December 5, 2011, from Who Do You Think You Are Web site: http://www.whodoyouthinkyouarelive.co.uk

24. $\quad$ Evans, R. (1998). The Visitor's Guide to Northern Ireland. Belfast: The Blackstaff Press Limited.

25. Ferguson, B. (2011, March 17). Rift at the top of Edinburgh City Council is exposed over The Gathering. The Scotsman. Retrieved December 7, 2011, from The Scotsman Web site: http://www.scotsman.com/news/rift_at the top_of edinburgh city_council_is exposed over the gatherin g_1_1532271

26. Fischer, P., Sauer, A., Vogrincic, C., \& Weisweiler, S. (2011). The ancestor effect: Thinking about our genetic origin enhances intellectual performance. European Journal of Social Psychology, 41, 11-16.

27. Fitzgerald, P. (2005). 'Come back Paddy Reilly': Aspects of Irish return migration 1600-1850. In M. Harper (Ed.), Emigrant homecomings: The return movement of emigrants 1600-2000. Manchester: Manchester University Press, 32-54.

28. The Genealogy Center. (2008). The Genealogy Center. Print advertisement, Ft. Wayne, Indiana, Indiana 2008 Travel Guide, VisitIndiana.com, 55.

29. Giddens, A. (1991). Modernity and self-identity: Self and society in the late modern age. Cambridge: Polity Press.

30. Gould, S.J. (2010). "To thine own self(ves) be true": Reflexive insights for etic self theory from consumers' emic constructions of the self. Consumption Markets \& Culture, 13(2), 181-219.

31. Hallissy, M. (2006). Reading Irish-American fiction: The hyphenated self. New York: Palgrave MacMillan.

32. Horne, D. (1992). The intelligent tourist. McMahons Point, New South Wales: Margaret Gee.

33. Huang, W., Haller, W. J., \& Ramshaw, G. (2012-in press). Diaspora tourism and homeland attachment: an exploratory analysis. Tourism Analysis.

34. Learmans, R. (1993). Bringing the consumer back in. Theory, Culture and Society, 10(1), $153-61$.

35. Levitz, J. (2010, October 14). Halloween doesn't fully explain the spike in powdered-wig sales. Wall Street Journal, A1.

36. Lunney, L. (2009). A view from the eastern shore of the Atlantic: Another way to look at emigration? Familia, 25, 82-93.

37. Lunney, L. (2011). “The 1718 Migration,” talk to North of Ireland Family History Society-Belfast Branch, 3 March.

38. Mackenzie, G., Slater, G., \& Roberts, H. (2004, March). Family history and tourism, listening to the past, speaking to the future: The report of the archives task force. London: Museums, Libraries and Archives Council. 
39. MacMaster, R.K. (2011). Scotch-Irish identity in eighteenth-century Pennsylvania. Proceedings of the Sixth Scotch-Irish Identity Symposium: The Scotch-Irish and their Culture, June 2-5, York, SC.

40. McCain, G., \& Ray, N.M. (2003). Legacy tourism: The search for personal meaning in heritage travel. Tourism Management, 24(6), 713-717.

41. Mkono, M. (2011). Authenticity does matter. Annals of Tourism Research, 39(1/January), 480-483.

42. Nicholls, S., Vogt, C., \& Jun, S.H. (2004). Heeding the call for heritage tourism. Parks \& Recreation, September, 38-47.

43. Pearce, Philip L. (2012). The experience of visiting home and familiar places. Annals of Tourism Research, 39(2/April), 1024-1047.

44. Ray, N.M., \& McCain, G. (2009a). Guiding tourists to their ancestral homes. International Journal of Culture, Tourism and Hospitality Research, 3(4), 296-305.

45. Ray, N.M. and McCain, G. (2009b). It was the trip of a lifetime: Viking ancestors, their descendants and their legacy tourism motivations and behavior, Proceedings of 2009 World Marketing Congress. Oslo, Norway. 188-196.

46. Roe, M. D., Schaafsma, T., \& Gutierrez, J. (2009). Meanings, functions, maintenance and reproduction of present-day Scotch-Irish social identities: The role of symbolic ethnicity. Journal of Scotch-Irish Studies, 3(1), 1-28.

47. Rosedale, J. H. (1996). The Ikdal Family History. Bountiful, UT: Family History Publishers. Originally printed in 1947, Chicago: Stromberg, Allen and Co.

48. Santos, C., \& Yan, G. (2009). Genealogical tourism: A phenomenological examination. Journal of Travel Research, 49, 56-67.

49. Sekhon, Y.K., \& Szmigin, I. (2011). Acculturation and identity: Insights from second-generation Indian Punjabis, Consumption, Markets \& Culture, 14(1), 79-98.

50. Sierra, J.J., \& McQuitty, S. (2007). Attitudes and emotions as determinants of nostalgia purchases: An application of social identity theory. Journal of Marketing Theory and Practice, 15(2), 99-112.

51. Silberberg, T. (1995). Cultural tourism and business opportunities for museums and heritage sites. Tourism Management, 16(5), 361-65.

52. Tergesen, A. (2011, May 9). Face to face with your past. Wall Street Journal, R5.

53. Walker, B. (2009). The Scotch-Irish in America today: Numbers, distribution, and identity. Journal of Scotch-Irish Studies, 3(1), 29-38.

54. Webb, Sen. J. (2004). Born Fighting: How the Scots-Irish shaped America. New York: Broadway Books.

55. Yale, P. (2004). From tourist attractions to heritage tourism. Huntingdon, UK: ELM Publications. 1-40.

56. Young, J. (2011). Personal communication. 
NOTES 